Sains Peternakan Vol. 6 (2), September 2008: 10-17

ISSN 1693-8828

\title{
Penerapan Teknologi Force Molting pada Ayam Petelur Afkir: Kajian Parameter Produksi, Organ Pencernaan dan Reproduksi, Pertahanan Tubuh
}

\author{
Ali Mursyid Wahyu Mulyono, Ahimsa Kandi Sariri dan Wisnu Tri Husodo \\ Fakultas Pertanian, Universitas Veteran Bangun Nusantara \\ Jl. Letjen Sujono Humardani No. 1, Sukoharjo 57521. Tel. +62-0271-593156, \\ fax.+62-0271-591065, \\ Email:alimursyid_wm@yahoo.com
}

\begin{abstract}
Abstrak
Penelitian bertujuan mempelajari parameter produksi telur, alat pencernaan dan reproduksi, dan pertahanan tubuh dari penerapan teknologi force molting (FM) pada ayam petelur afkir. Tiga puluh enam ekor ayam petelur afkir secara acak didistribusikan ke dalam 2 macam perlakuan (T0 dan T1), yang masing-masing terdiri dari 3 ulangan. Setiap ulangan terdiri 6 ekor ayam. T0 (kontrol) adalah pemberian ransum ad libitum selama penelitian. T1 adalah perlakuan FM metode puasa pakan 6 hari dilanjutkan pembatasan pakan (jagung 50 g/ekor/hari) selama 29 hari. Pasca perlakuan, ayam-ayam T1 diberi ransum seperti pada T0 selama 3 x periode 28 hari. Air minum diberikan ad libitum. Variabel yang diamati meliputi performan produksi dan kualitas telur, panjang dan bobot bagian-bagian saluran pencernaan dan reproduksi, dan profil darah. Hasil penelitian menunjukkan bahwa perlakuan FM pada ayam petelur afkir secara nyata meningkatkan persentase produksi telur, bobot produksi telur, dan menurunkan konversi pakan, namun tidak berpengaruh nyata terhadap konsumsi pakan dan kualitas telur. Bobot dan panjang bagian-bagian saluran pencernaan dan reproduksi tidak nyata dipengaruhi perlakuan FM kecuali bobot gizzard, magnum dan uterus, dan panjang isthmus. Perlakuan FM tidak nyata mempengaruhi parameter pertahanan tubuh. Penelitian disimpulkan bahwa teknologi force molting pada ayam petelur afkir dapat mengaktifkan kembali produksi telur tanpa mempengaruhi bagian-bagian organ pencernaan dan reproduksi, dan pertahanan tubuh.
\end{abstract}

Kata kunci: Force molting, ayam petelur afkir, produksi telur, pertahanan tubuh, saluran pencernaan dan reproduksi

\section{The Application of Force Molting Technology on Rejected Laying Hen: Production, Digestion and Reproduction Organ, and Body Protection Parameters}

\begin{abstract}
The research was aimed to study the egg production, digestion and reproduction tract, and body protection parameters of the force molting (FM) technology application on rejected laying hen. Thirty-six rejected laying hens were randomly devided into two kinds of treatment (T0 and T1), with three replication each. Each replication consisted of six hens. T0 (control) was ad libitum feeding during the research. T1 was FM treatment of six-days feed fasting, continued by restricted feeding (corn $50 \mathrm{~g} / \mathrm{hen} /$ day) for 29 days. After the treatment, T1 was fed as T0 for $3 \times 28$ days period. Water was given ad libitum for T0 and T1. Variables
\end{abstract}


observed included production and egg quality, length and weight of the parts of digestion and reproduction tract, and blood profile. The result of the research showed that FM treatment on rejected laying hens significantly increased the percentage of egg production and eggmass, decreasing feed conversion ratio, but it insignificantly influenced on feed consumption and egg quality. The weight and length of the parts of digestion and reproduction tract were insignificantly influenced by FM treatment, except of gizzard, magnum and uterus weight, and isthmus length. The FM treatment was insignificantly influenced the body protection parameters. It was concluded that the force molting technology on rejected laying hen could re-activation of egg production without effecting on the parts of digestion and reproduction organ, and body protection parameters.

Key words: Force molting, rejected laying hen, egg production, digestion and reproduction tract, body protection

\section{PENDAHULUAN}

Ayam petelur mampu bertelur lebih dari 260 butir per tahun produksi hen house dengan usia produktif berkisar $22-72$ minggu (Rasyaf, 1994). Selanjutya dijelaskan bahwa dalam ovarium ayam terdapat sekitar 3000 ovum. Ini berarti jumlah ovum yang belum menjadi telur setelah masa produktif selesai masih sangat banyak. Ayam petelur dianggap tidak layak dipelihara lagi bila biaya produksi sudah lebih tinggi dari penerimaan penjualan telur. Ayam ini sering disebut ayam afkir.

Hampir semua peternak lebih senang menjual ayam petelur afkir karena harga ditingkat pengecer sama dengan harga ayam broiler per kilogram. Selain itu peternak tidak mengetahui bahwa sebenarnya ayam afkir tersebut masih dapat dipacu kembali produksi telurnya dengan melakukan force molting

Rasyaf (1994) menyatakan force molting merupakan tindakan merontokkan bulu dengan menghentikan produksi telur yang waktunya diatur oleh manusia. Tindakan force molting bertujuan agar ayam mempunyai waktu istirahat bertelur, yang selanjutnya siap bertelur lagi di masa produksi berikutnya. Harimurti et al. (1979) menyatakan bahwa ditinjau dari segi ekonomi force molting dapat memperpanjang produksi telur, sehingga mampu mendayagunakan ayam petelur yang sudah waktunya afkir.
Handayani (1980) menyatakan bahwa force molting dapat menaikkan produksi telur, mempengaruhi konsumsi pakan, dan dalam perhitungan ekonomi lebih menguntungkan. Force molting juga mampu meningkatkan kualitas telur (Hurwitz, 1974). Bila selama perlakuan force molting ayam benar-benar berhenti bertelur, dapat diduga nanti di masa produksi berikutnya, ayam akan bertelur banyak dan ukurannya lebih besar (Rasyaf, 1994). Alodan and Mashaly (1999) melaporkan bahwa perlakuan induced molting tidak berpengaruh terhadap jumlah antibodi dan kekebalan tubuh ayam petelur.

Perlakuan force molting sangat memungkinkan berdampak pada efisiensi penggunaan bibit dan biaya regenerasi. Bagi daerah yang jauh dari pusat pembibitan ayam petelur perlakuan juga dapat mengatasi ketergantungan DOC, sehingga tidak terlalu mengganggu kesinambungan produksi telur.

Ada beberapa metode force molting yang dapat diterapkan yakni, pembatasan pakan, minum, cahaya dan pemberian obatobatan (Alodan and Mashaly, 1999). Metode yang cocok dengan kondisi iklim di Indonesia adalah pembatasan pakan.

Mulyono dan Husodo (2004) melaporkan bahwa proses produksi ayam petelur afkir dapat diaktifkan kembali melalui perlakuan force molting dengan metode puasa makan total selama 6 hari dan dilanjutkan pembatasan pemberian pakan 
yaitu berupa jagung kuning giling sebanyak $54 \mathrm{~g} /$ ekor/hari sampai dengan hari ke 30 . Namun pada penelitian tersebut belum dikaji secara komprehensif yakni aspek ekonomi, respon kekebalan tubuh, perubahan histologi organ pencernaan dan reproduksi dari penerapan teknologi force molting.

Pada sisi lain, potensi ayam petelur afkir di jawa tengah begitu tinggi. Hal ini selaras dengan populasi ayam petelur pada tahun 2001 di Jawa Tengah yang mencapai 7,11 juta ekor, sedangkan populasi nasional 66,9 juta ekor (BPS, 2005).

Penelitian yang komprehensif tentang penerapan teknologi force molting pada ayam petelur afkir, kedepan dapat menelurkan paket teknologi yang cocok untuk dikembangkan di pedesaan dengan memanfaatkan ayam afkir dari perusahaan besar.

Penelitian ini bertujuan mempelajari pengaruh force molting pada ayam petelur afkir terhadap produksi telur, organ pencernaan dan reproduksi, dan pertahanan tubuh.

\section{MATERI DAN METODE}

\section{Ayam dan ransum}

Penelitian menggunakan ayam petelur afkir umur 86 minggu sebanyak 36 ekor. Ransum ayam petelur dengan komposisi jagung kuning giling $45 \%$, dedak halus $17 \%$ dan konsentrat ayam petelur CP 124 produksi PT. Charoen Phokpand 38\%.

\section{Rancangan Percobaan}

Percobaan dirancang dengan rancangan acak lengkap (RAL) pola searah. Tiga puluh enam ekor ayam petelur afkir umur 86 minggu secara acak didistribusikan ke dalam 2 macam perlakuan. Setiap perlakuan terdiri dari 3 ulangan. Setiap ulangan menempati kandang batere yang terdiri dari 6 ruang untuk 6 ekor ayam. Macam perlakuan pertama (T0) adalah kontrol. Ayam pada T0 ini diberi ransum ayam petelur secara at libitum selama penelitian. Macam perlakuan ke-2 (T1) adalah penerapan teknologi force molting (FM) seperti yang dilakukan Mulyono dan Husodo (2004), yaitu pembatasan pakan berupa pemuasaan total pada ayam selama 6 hari. Pasca pemuasaan total, ayam-ayam pada T1 diberi pakan jagung kuning giling yang dibatasi sebesar $50 \mathrm{~g} / \mathrm{ekor} /$ hari sampai hari ke-35. Pasca penerapan teknologi force molting, ayam-ayam T1 diberi ransum ayam petelur seperti pada T0 selama $2 \mathrm{x}$ periode 28 hari. Selama perlakuan, air minum diberikan secara ad libitum.

\section{Produksi dan kualitas telur}

Produksi dan kualitas telur yang diamati meliputi konsumsi pakan (KP, g/ekor/hari), produksi telur (hen day average, HDA, \%), bobot telur (BT, $\mathrm{g} /$ butir), konversi pakan (feed corvesion ratio, FCR), tebal kerabang ( $\mathrm{mm})$, dan bobot kerabang (g/butir).

$\mathrm{FCR}=\mathrm{KP} \quad(\mathrm{g} /$ ekor/hari $) /[\mathrm{BT}$ (g/butir) x HDA (\%)]

\section{Saluran pencernaan dan reproduksi}

$\begin{array}{cccc}\text { Ayam } & \text { dipotong } & \text { segera } & \text { setelah } \\ \text { pengambilan } & \text { sampel } & \text { darah. } & \text { Saluran }\end{array}$ pencernaan (meliputi proventrikulus, gizzard, duodenum, jejenum+ileum, sekum, dan kolon) dan saluran reproduksi (meliputi infudibulum, magnum, isthmus, uterus, vagina) diambil dipotong-potong pada setiap bagian untuk diukur bobot dan panjangnya. Berdasarkan bobot dan panjang riil pada setiap bagian, dihitung bobot relatif $(\mathrm{g} / \mathrm{kg}$ bobot badan dan panjang relatif $(\mathrm{cm} / \mathrm{kg}$ bobot badan).

\section{Profil darah}

Pasca penimbangan bobot badan awal (Pra FM), saat HDA 0\% (Saat FM), dan akhir penelitian (Pasca FM) dilakukan pengambilan sampel darah ayam melalui heart puncture seperti yang dilakukan Lee et al. (2004). Sampel darah diambil dari ayam 
yang bobotnya paling dekat dengan rerata pada setiap ulangan. Sampel darah dicampur dengan antikoagulan dan segera dibawa ke laboratorium untuk analisis profil darah. Profil darah yang diukur meliputi eritrosit (red blood cell, RBC, juta sel/ $\mu \mathrm{l}$ ), lekosit (sel/ $\mu \mathrm{l})$, hemoglobin $(\mathrm{Hb}, \mathrm{g} / \mathrm{dl})$, hematokrit (packed cell volume, $\mathrm{PCV}, \%$ ), total protein plasma (TPP, g/dl), neutrofil (\%), limfosit $(\%)$, dan monosit (\%).

\section{Analisis Data}

Data produksi dan kualitas telur dianalisis dengan uji t (Gaspersz, 1991) untuk mengetahui perbedaan antara $\mathrm{T} 0$ dan T1. Data variabel profil darah, organ digesti, dan reproduksi dianalisis dengan Analisis Variansi (ANOVA) Pola Searah, dengan uji lanjutan Duncan (Gaspersz, 1991) untuk mengetahui perubahan hasil pengukuran dari Pra, Saat dan Pasca FM.

\section{HASIL DAN PEMBAHASAN}

\section{Produksi telur}

Perlakuan force molting terhadap ayam afkir mampu meningkatkan produksi telur harian $(\mathrm{P}<0,05)$ dan menurunkan konversi pakan $(\mathrm{P}<0,05)$, namun tidak berpengaruh terhadap konsumsi pakan, bobot telur, bobot kerabang, dan tebal kerabang $(\mathrm{P}>0,05) \quad($ Tabel 1). Perbaikan produksi telur dan konversi pakan pada penelitian ini selaras dengan Handayani (1980), Harun (1980) dan Hoyle dan Girlic (1987).

Tabel 1. Pengaruh perlakuan force molting (FM) pada ayam petelur afkir terhadap produksi telur

\begin{tabular}{|c|c|c|}
\hline Variabel & Tanpa perlakuan FM & Diberi perlakuan FM \\
\hline Konsumsi pakan (g/ekor/hari) ${ }^{\text {ns }}$ & 105,4 & 106,0 \\
\hline Produksi telur harian (\%) & $59,4^{b}$ & $70,8^{\mathrm{a}}$ \\
\hline Konversi pakan & $2,57^{\mathrm{a}}$ & $2,23^{\mathrm{b}}$ \\
\hline Bobot telur $(g)^{\text {ns }}$ & 69,07 & 67,13 \\
\hline Bobot kerabang (g) ${ }^{\mathrm{ns}}$ & 7,57 & 7,57 \\
\hline Tebal kerabang $(\mathrm{mm})^{\mathrm{ns}}$ & 0,03 & 0,03 \\
\hline
\end{tabular}

Kondisi kekurangan nutrien pada ayam yang mendapatkan perlakuan force molting ketika puasa pakan total dan pembatasan pakan berakibat proses peneluran berhenti selama 4 minggu (Gambar 1). Hal ini terjadi akibat kurangnya konsumsi energi dan nutrien lain sehingga proses pembentukan telur terganggu (Yunanto et al., 1998). Pada saat istirahat produksi terjadi refreshing dan perbaikan organ reproduksi (Rasyaf, 1994) sehingga mampu menaikkan kembali produksi telur pasca force molting.

Produksi telur ayam yang diberi perlakuan menurun sampai dengan $0 \%$ pada saat perlakuan force molting diterapkan. Pada minggu ke 7 , ketika pakan diberikan normal kembali maka produksi telur mulai ada peningkatan. Mulai minggu ke 8 terjadi peningkatan produksi yang sangat cepat sampai dengan tercapainya puncak produksi pada minggu ke 10. Pada minggu-minggu berikutnya produksi telur sedikit demi sedikit menurun hingga pada minggu ke 16 produksi berada pada tingkat $69 \%$.

Pada ayam petelur afkir yang tidak diberi perlakuan force molting, produksi telur harian cenderung konstan pada kisaran 48-68\% dengan rerata 59,4\%. Perbandingan kurva produksi telur (Gambar 1) membuktikan bahwa ayam petelur afkir dapat diaktifkan kembali produksi telurnya dengan perlakuan force molting. 


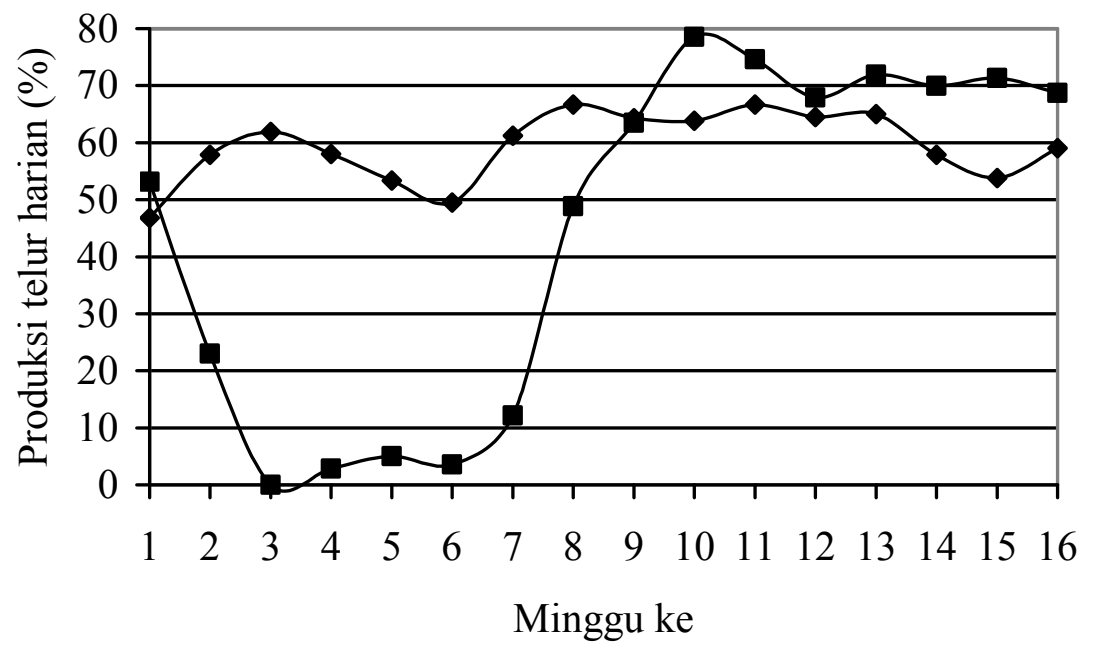

Gambar 1. Kurva produksi telur ayam petelur afkir yang tidak diberi (-๑-) dan yang diberi (-) perlakuan force molting

\section{Bobot badan, saluran pencernaan dan reproduksi}

Pada saat ayam menerima perlakuan force molting, bobot badan menurun sangat nyata $(\mathrm{P}<0,01)$ dari 1937 menjadi $1608 \mathrm{~g}$. Selain penurunan bobot, ayam juga mengalami rontok bulu. Pada akhir penelitian, bobot badan ayam meningkat kembali secara sangat nyata $(\mathrm{P}<0,01)$ menjadi 1786 g. Kondisi ini menunjukkan bahwa penurunan bobot karena keterbatasan nutrien akan berakibat terjadinya compensatory gain setelah pakannya kembali normal.

Penurunan bobot dan rontok bulu disebabkan puasa dan pembatasan pakan pada program force molting. Ayam tidak mampu lagi mempertahankan bulu, karena nutrien utama bulu adalah protein, sedangkan pakan pada ayam ini hanya jagung kuning yang kandungan proteinnya sangat rendah. Puasa makan total selama 6 hari yang dilanjutkan dengan pembatasan pakan selama 29 hari berakibat pakan yang dikonsumsi tidak dapat mencukupi kebutuhan energi hidup pokok, sehingga nutrien tubuh terdegradasi yang berakibat bobot badan menurun.

Bobot dan panjang relatif bagianbagian saluran pencernaan menunjukkan hasil yang tidak nyata berbeda, kecuali bobot gizzard (Tabel 2). Bobot dan panjang bagian-bagian saluran pencernaan secara umum tidak mengalami perubahan nyata pada saat ayam afkir menerima perlakuan force molting maupun setelah kembali berproduksi telur. Bobot gizzard meningkat tidak nyata pada saat ayam mengalami perlakuan force molting, kemudian menurun nyata $(\mathrm{P}<0,05)$ setelah ayam kembali berproduksi telur.

Bobot relatif organ pencernaan tambahan meliputi hepar, pankreas dan lien menunjukkan hasil yang tidak nyata berbeda pada saat ayam afkir menerima perlakuan force molting maupun setelah kembali berproduksi telur. Hal ini menunjukkan bahwa perlakuan force molting tidak mengakibatkan perubahan yang fluktuatif pada proses metabolisme ayam.

Perlakuan force molting tidak berpengaruh nyata terhadap bobot dan panjang relatif bagian-bagian saluran reproduksi, kecuali bobot magnum dan uterus (Tabel 3).

Bobot magnum menurun nyata $(\mathrm{P}<0,05)$ pada saat ayam mengalami perlakuan force molting, kemudian meningkat kembali secara nyata $(\mathrm{P}<0,05)$ setelah ayam kembali berproduksi telur. Magnum adalah tempat terjadinya sekresi albumen telur (Yuwanta, 2004). Pada saat ayam tidak berproduksi telur maka magnum 
kurang aktif dan menunjukkan bobot yang menurun. Setelah ayam aktif kembali berproduksi maka magnum akan kembali aktif dan bobotnya meningkat.

Bobot uterus menurun nyata $(\mathrm{P}<0,05)$ pada saat ayam mengalami perlakuan force molting (ayam tidak berproduksi telur) dan tidak meningkat lagi ketika produksi telur ayam kembali meningkat. Hal ini membuktikan bahwa meskipun bobot uterus dari ayam yang diberi perlakuan force molting menurun namun tetap mampu mensekresikan mineral untuk membentuk kerabang telur yang kualitasnya tidak berbeda dengan ayam yang tidak mendapat perlakuan force molting.

Panjang isthmus mengalami kenaikan nyata $(\mathrm{P}<0,05)$ setelah ayam kembali aktif berproduksi telur (pasca perlakuan force molting). Hal ini membuktikan bahwa setelah ayam menerima pakan secara normal, aktivitas sekresi albumen pada isthmus kembali meningkat untuk mendukung peningkatan produksi telur.

Tabel 2. Bobot dan panjang relatif bagian-bagian saluran pencernaan ayam petelur afkir pada sebelum (pra), saat dan pasca perlakuan force molting (FM)

\begin{tabular}{|c|c|c|c|}
\hline Variabel & Pra FM & Saat FM & Pasca FM \\
\hline Bobot proventrikulus, $\mathrm{g} / \mathrm{kg} \mathrm{BB}^{\mathrm{ns}}$ & 4,00 & 3,40 & 3,87 \\
\hline Bobot gizzard, g/kg BB & $13,17^{\mathrm{a}}$ & $16,50^{\mathrm{a}}$ & $9,43^{b}$ \\
\hline Bobot duodenum, $\mathrm{g} / \mathrm{kg} \mathrm{BB}^{\mathrm{ns}}$ & 4,57 & 3,80 & 5,23 \\
\hline Panjang duodenum, $\mathrm{cm} / \mathrm{kg} \mathrm{BB}^{\mathrm{ns}}$ & 14,23 & 16,20 & 13,80 \\
\hline Bobot jejunum+ileum, $\mathrm{g} / \mathrm{kg} \mathrm{BB}{ }^{\text {ns }}$ & 12,37 & 11,67 & 11,97 \\
\hline Panjang jejenum + ileum, $\mathrm{cm} / \mathrm{kg} \mathrm{BB}{ }^{\mathrm{ns}}$ & 64,00 & 72,07 & 67,97 \\
\hline Bobot sekum, $\mathrm{g} / \mathrm{kg} \mathrm{BB}{ }^{\mathrm{ns}}$ & 3,57 & 3,80 & 3,03 \\
\hline Panjang sekum, $\mathrm{cm} / \mathrm{kg} \mathrm{BB}{ }^{\mathrm{ns}}$ & 8,20 & 9,87 & 9,00 \\
\hline Bobot kolon, $\mathrm{g} / \mathrm{kg} \mathrm{BB}{ }^{\mathrm{ns}}$ & 1,93 & 2,47 & 1,83 \\
\hline Panjang kolon, $\mathrm{cm} / \mathrm{kg} \mathrm{BB}{ }^{\mathrm{ns}}$ & 3,43 & 4,00 & 3,60 \\
\hline Bobot hepar, $\mathrm{g} / \mathrm{kg} \mathrm{BB}{ }^{\mathrm{ns}}$ & 23,27 & 24,47 & 18,00 \\
\hline Bobot pankreas, $\mathrm{g} / \mathrm{kg} \mathrm{BB}{ }^{\mathrm{ns}}$ & 2,03 & 1,93 & 1,60 \\
\hline Bobot lien, $\mathrm{g} / \mathrm{kg} \mathrm{BB}{ }^{\mathrm{ns}}$ & 2,87 & 2,03 & 1,73 \\
\hline
\end{tabular}

Tabel 3. Bobot dan panjang relatif bagian-bagian saluran reproduksi ayam petelur afkir pada sebelum (pra), saat dan pasca perlakuan force molting (FM)

\begin{tabular}{|c|c|c|c|}
\hline Variabel & Pra FM & Saat FM & Pasca FM \\
\hline Bobot infudibulum, $\mathrm{g} / \mathrm{kg} \mathrm{BB}{ }^{\mathrm{ns}}$ & 1,33 & 1,93 & 1,23 \\
\hline Panjang infudibulum, $\mathrm{cm} / \mathrm{kg} \mathrm{BB}{ }^{\text {ns }}$ & 5,60 & 8,27 & 5,60 \\
\hline Bobot magnum, $\mathrm{g} / \mathrm{kg} \mathrm{BB}$ & $20,70^{\mathrm{a}}$ & $10,67^{\mathrm{b}}$ & $17,77^{\mathrm{a}}$ \\
\hline Panjang magnum, $\mathrm{cm} / \mathrm{kg} \mathrm{BB}{ }^{\mathrm{ns}}$ & 21,67 & 17,63 & 16.63 \\
\hline Bobot isthmus, $\mathrm{g} / \mathrm{kg} \mathrm{BB}{ }^{\mathrm{ns}}$ & 3,93 & 3,03 & 4,40 \\
\hline Panjang isthmus, $\mathrm{cm} / \mathrm{kg} \mathrm{BB}$ & $6,27^{\mathrm{b}}$ & $5,97^{\mathrm{b}}$ & $8,73^{\mathrm{a}}$ \\
\hline Bobot uterus, $\mathrm{g} / \mathrm{kg} \mathrm{BB}$ & $11,80^{\mathrm{a}}$ & $7,63^{b}$ & $7,57^{\mathrm{b}}$ \\
\hline Bobot vagina, $\mathrm{g} / \mathrm{kg} \mathrm{BB}{ }^{\text {ns }}$ & 3,40 & 3,37 & 2,63 \\
\hline \multicolumn{4}{|c|}{$\begin{array}{l}{ }^{\mathrm{a}, \mathrm{b}} \text { Superskrip pada kolom yang sama menunjukkan perbedaan signifikan }(\mathrm{P}<0,05) \\
\text { ns } \\
\text { Menunjukkan perbedaan tidak signifikan }(\mathrm{P}>0,05) \text {. BB adalah bobot bad }\end{array}$} \\
\hline Profil darah & \multirow{2}{*}{\multicolumn{3}{|c|}{$\begin{array}{l}\text { dan monosit) menunjukkan hasil yang tidak } \\
\text { nyata berbeda }(\mathrm{P}>0,05) \text { baik sebelum, pada } \\
\text { saat, maupun pasca perlakuan force molting } \\
(\text { Tabel } 4) \text {. }\end{array}$}} \\
\hline $\begin{array}{l}\text { rofil darah yang berhubungan den } \\
\text { nan tubuh (lekosit, neutrofil, lim }\end{array}$ & & & \\
\hline
\end{tabular}


Hasil ini menunjukkan bahwa teknologi force molting dengan metode puasa pakan total selama 6 hari, dilanjutkan pembatasan pakan selama 29 hari dapat diterapkan tanpa mempengaruhi daya tahan tubuh. Profil darah lain, seperti eritrosit, hemoglobin, dan volume sel darah menunjukkan hasil yang signifikan $(\mathrm{P}<0,05)$ dengan kecenderungan yang sama, yakni meningkat pada saat diberi perlakuan force molting, kemudian menurun kembali seperti pada sebelum perlakuan, setelah lepas dari perlakuan pembatasan pakan.

Tabel 4. Profil darah ayam petelur afkir pada sebelum (pra), saat dan pasca perlakuan force molting (FM)

\begin{tabular}{|c|c|c|c|}
\hline Variabel & Pra FM & Saat FM & Pasca FM \\
\hline $\mathrm{RBC}, \mathrm{juta} / \mu \mathrm{l}$ & $1,89^{b}$ & $2,36^{\mathrm{a}}$ & $1,89^{b}$ \\
\hline Leukosit, $/ \mu 1^{\mathrm{ns}}$ & 3883,30 & 6483,30 & 6616,67 \\
\hline $\mathrm{Hb}, \mathrm{g} / \mathrm{dl}$ & $5,20^{b}$ & $7,40^{\mathrm{a}}$ & $4,17^{b}$ \\
\hline $\mathrm{PCV}, \%$ & $23,00^{\mathrm{b}}$ & $27,00^{\mathrm{a}}$ & $20,33^{b}$ \\
\hline $\mathrm{TPP}, \mathrm{g} / \mathrm{dl}^{\mathrm{ns}}$ & 4,99 & 6,33 & 4,77 \\
\hline Neutrofil segmen, $\%{ }^{n s}$ & 33,33 & 57,00 & 49,00 \\
\hline Limfosit, $\%$ ns & 57,00 & 31,33 & 27,67 \\
\hline Monosit, \% ${ }^{\mathrm{ns}}$ & 9,67 & 11,67 & 23,33 \\
\hline
\end{tabular}

\section{KESIMPULAN}

Teknologi force molting pada ayam petelur afkir dapat mengaktifkan kembali produksi telur tanpa mempengaruhi bagianbagian organ pencernaan dan reproduksi, dan pertahanan tubuh.

\section{UCAPAN TERIMA KASIH}

Terima kasih diucapkan kepada Dinas Pendidikan dan Kebudayaan, Pemerintah Provinsi Jawa Tengah yang telah mendanai penelitian ini melalui Program Penelitian Pemula, Fasilitasi Perguruan Tinggi, Tahun 2005.

\section{DAFTAR PUSTAKA}

Alodan, M.A. and M.M. Mashaly. 1999. Effect of Induced Molting in Laying Hens on Production and Immune Parameters. Poultry Sci., 78:171177.

BPS. 2005. Badan Pusat Statistik. Dari:

http://www.bps.go.id/sector/agri/tern ak/table3.shtml. dan http://jateng.bps.go.id/b0414.htm.

Gespersz, V. 1991. Metode Perancangan Percobaan. CV. Armico. Bandung.

Handayani, A.S 1980. Pengaruh Induce Molting Terhadap Produktifitas Ayam Petelur. Laporan Penelitian, Fakultas Peternakan. UGM. Yogyakarta.

Harimurti, S.J.H. Purba, M. Anwar, dan Nasution. 1979. Pengaruh Induce Molting Terhadap Performans Petelur. Laporan Penelitian, Fakultas Peternakan. UGM. Yogyakarta.

Harun, H. 1980. Pengaruh Induce Molting Terhadap Kualitas Telur. Laporan Penelitian, Fakultas Peternakan. UGM. Yogyakarta.

Hoyle and Garlich. 1987. Pos Fasting Dietery Protein Requirement of Induced Molted Hend. Poultry Sci. 66: 1973-1979.

Hurwitz, 1974. Some Respons of Laying to Induced Arrest of Egg Production. Poultry Sci. 54. 
Lee, K.-W., H. Everts, H.J. Kappert, H. Wouterse, M. Frehner and A.C. Beynen. 2004. Cinnamaldehyde, but not Thymol, Counteracts the Carboxymethyl Cellulose-induced Growth Deppression in Female Broiler Chickens. Int. J. of Poultry Sci., 9: 608-612.

Mulyono, A.M. dan W.T. Husodo. 2004. Variasi Puasa Pakan pada Perlakuan Force Molting untuk Pengaktifan
Kembali Produksi Ayam Petelur Afkir. Laporan Penelitian, Proyek Peningkatan Kopertis Wilayah VI. Fakultas Pertanian, Universitas Veteran Bangun Nusantara. Sukoharjo.

Rasyaf, M. 1994. Beternak Ayam Petelur. Penebar Swadaya. Jakarta.

Yuwanta, T. 2004. Dasar Ternak Unggas. Kanisius. Yogyakarta. 